Research Article

\title{
Investigation of the effects of religious music education practices on perceived stress levels of gifted students ${ }^{1}$
}

\author{
Recep Dereli ${ }^{2}$
}

Kecioren Science and Art Center, Turkey

\section{Article Info}

Received: 27 March 2021

Revised: 15 May 2021

Accepted: 08 June 2021

Available online: 15 June 2021

Keywords:

Gifted student

Music education

Perceived stress

Religious music

2717-8870 / (C) 2021 The Authors. Published by Young Wise Pub. Ltd. This is an open access article under the CC BY-NC-ND license

\begin{abstract}
The main purpose of this study is to find an answer to the question "Does Turkish religious music education practices have a positive effect on the perceived stress levels of gifted students?" For the purpose of the study, a total of 305 students between the ages of 8 and 18, studying at Science and Art Centers providing education to gifted students across Ankara, constituted the control group of the study and the data collection tool was applied to this group. In addition, 25 students who were diagnosed with gifted in the field of music formed the experimental group and were subjected to 10 -weeks religious music education by the researcher, after these training, the data collection tool was also applied to these students. When the findings of the study are examined, it is concluded that religious music education practices do not affect perceived stress levels positively or negatively
\end{abstract}

\section{To cite this article}

Dereli, R. (2021). Investigation of the effects of religious music education practices on perceived stress levels of specially talented children. Journal for the Interdisciplinary Art and Education, 2(1), 33-43. DOI: http://dx.doi.org/10.29228/jiae.13

\section{Introduction}

Individuals may be faced with daily, private or professional life stress. The person, even if only a little, has left writing about stress or took part in stressful environments for some part of his life. In a sense, stress is the pure reality that finds its place in the life of the individual. In addition to being an important mechanism in a person's life, stress is accepted as an integral part of life (Selye, 1956). On the other hand, if stress is experienced at a low level, like all other emotions, its effect will be positive, and if it is experienced at an extreme level, it may have negative effects on the person.

In today's societies, stress is considered an increasing problem for both health and society. In business life, educational environments can be added to this, and there are many factors that contribute to perceived stress (Mark \& Smith, 2008). All living things are always under stress for many reasons. Because of a short-term increase in the short time they live in daily life, individuals may be physically worn or written (Selye, 1965).

In fact, you can achieve success in order to cope with stress, to achieve success, to get chances for success. In contrast, individuals still dislike these stressful situations, as they spend their capacity to isolate them from major events (Tachè \& Selye, 1985). Other challenges include personality traits that make it difficult to do these stressful challenges. Grudge, hostility, etc. Individuals with emotions, those who accuse themselves of almost every issue, who stand out with their over-sensitive and emotional reactions, egoists, those who look at life with the "all or nothing" rule, passive and childish individuals cannot be successful in combating stress (Baltaş \& Baltaş, 2002: 43). 
Trying to cope with all this stressful life, human beings are the only creatures that have aesthetic feelings and can create melodies by interpreting the sounds they hear in the universe. At this point, the individual can play music with the sounds of the frequency he / she has the ability to hear with the limits of his throat. It has been observed in any society that even people who are impaired by their hearing or speaking abilities express their thoughts and feelings through music, the basis of which is sound, or manifest symptoms in musical style.

The individual sought a way to convey many different sociological or psychological situations expressed with courage, fear, sadness, happiness, joy, national or spiritual feelings with the help of music depending on the positive and negative situations he encountered in daily life in the society he lives in, and in this search process, has encountered many methods. Music that can be summarized as the harmony of melody and rhythm; It stands out compared to other art branches with its aspects that have been noticed by people since the past centuries and which make people peaceful, happy, and calm them in daily life. It is known that people living in primitive tribes in many parts of the world from the earliest times feared shamans and wizards of the tribe. In addition, it is understood that the same people respect these people, and as a result of this, the valuable position of the shaman and the sorcerer in the tribe. At this point, it is accepted that the shaman and the sorcerer are the "symbol of power" from the spiritual point of view, who are asked for help against the negativities experienced in parallel with the belief in the tribe (Güvenç, 1985: 1).

When the power of influence in society which are known to be at this level musicians who perform music with the music of the movement, although it is clear that in the historical process of the musical numbers are sanctified in Turkey. In this context, it is among the goals to convey music to the next generations with today's young people, and to enhance the century with rapidly changing and developing technologies (Öztürk, 2019: 2). Based on these explanations, the relationship of specially talented individuals with music, which is regarded as the cornerstone in the development of societies, becomes extremely important.

People who have been identified as having special talents; Even though they have very important roles in the development of societies, they are "different" in terms of their developmental characteristics compared to people with normal development, the pressure and responsibility created by the "special talent" identity determined for them, accordingly, high-level studies and achievements from the environment and the family itself. In the society where they live their lives due to their characteristics such as being awaiting and being mentally more advanced than their peers in the education and training process and getting bored quickly due to this, and having the "naughty student" stamp as a result of this boredom affecting other friends, teachers and lessons It is considered to be "disadvantaged" (Pfeiffer \& Stocking, 2000).

In addition, when investigating the developmental processes of individuals, the idea that "people with special talents are more advanced than people with normal development in all developmental areas" is wrong. In the studies conducted, it was found that although gifted individuals were advanced compared to their peers in terms of some developmental characteristics, some developed with their peers, and some were behind their peers in developmental characteristics (Saranl1, 2017). Due to this difference in the developmental area of gifted individuals, these individuals may face significant psychological problems due to their "disadvantaged" characteristics explained above (Neihart \& Yeo, 2018). However, the fact that special talented people can use their existing potentials in extremely negative and dangerous activities if they are deprived of good direction and education is also accepted as the other side of the coin.

In the studies conducted in the literature, it was seen that almost all teaching models for the education of children with special abilities were prepared to improve the development of these children in cognitive areas (Betts \& Neihart, 1985). It was determined that their development in affective and social aspects was ignored in the trainings provided in this context (Howard, 1995).

While examining the effects of music on individuals with special talents, whose importance in the life of the individual is tried to be explained, constitutes the basis of the study, the issue of stress, which is among the affective problems, has been tried to be brought to the fore in the study.

\section{The Purpose and Importance of the Research}

The aim of the study is to determine the effect of religious music education practices on the perceived stress of gifted children. This study was carried out on the basis of the hypothesis of minimizing negative effects such as perfectionism, test anxiety, high emotional intelligence, which are among the most common common features of gifted children in daily life, and stress based on this, with religious music practices. Since the study has a unique structure that has not been studied in the field before, it is important in terms of being a resource for academicians who plan to do academic studies in this field. 


\section{Problem of Study}

From this point of view, the main problem sentence of the study and the sub-problems related to the main problem sentence are as follows;

The main problem statement is;

$>$ Do religious music education practices have a positive effect on the perceived stress of gifted children? The subproblems are;

$>$ Is there any effect of the gender to implemented religious music education practices on the perceived stress of gifted children?

$>$ Is there any effect of the age to implemented religious music education practices on the perceived stress of gifted children?

$>$ Is there any effect of the grade to implemented religious music education practices on the perceived stress of gifted children?

$>$ Is there any effect of the education level of program to implemented religious music education practices on the perceived stress of gifted children?

$>$ Is there any effect of the interested music of parents to implemented religious music education practices on the perceived stress of gifted children?

\section{Assumptions}

While preparing the research;

$>$ Special talented students studying at Science and Art Centers objectively respond to the data collection tool of the study,

$>$ The measurement method determined to be used in the study is accurate, reliable and the measurement processes are carried out in a healthy way,

$>$ It is assumed that the person who will carry out the measurement and evaluation in the study has done this process objectively and reliably.

\section{Method}

\section{Research Model}

In the study, experimental method with control group was used. In this study, the elements planned to be tested were determined according to the determined purpose of the study. The data collection tool determined for the study was applied to the students in the control group. Trainings were carried out with the experimental group students within the framework of the "religious music education study program", which lasted a total of ten weeks. Learning environment; The covid-19 pandemic conditions were organized in a way that distance education was taken into account, taking into account the subjects and the suitability for the course and students, and the application was carried out taking into account the readiness levels of the students in the experimental group. The study was conducted in the form of distance education in the first semester of the 2020-2021 academic year and was completed within the targeted period. In order to perform the application remotely, the "Zoom" program, one of the Web 2.0 tools used in distance education, was used.

\section{Research Pattern}

The experimental design determined for the study, the independent variable whose effect on the experimental group was examined, is the "Inquiry Based Learning Approach". In the control group, the determined dependent variable was tried to be observed without any instruction. The same dependent variable (perceived stress level) was observed in both the control group and the experimental group, and this dependent variable was compared in both groups. In addition, the influence levels of this dependent variable and some independent variables (gender, education level, class and parents' level of interest in music) were also compared in the two groups. Out of 330 gifted students between the ages of 8-18, who are studying at Keçiören, Altındağ, Yenimahalle, Çubuk, Sincan, Etimesgut, Çankaya and Mamak Science and Art Centers in Ankara, 25 While the student formed the experimental group of the research, the remaining 305 students formed the control group of the study. At this point, the control group was randomly determined among the students studying at the aforementioned Science and Art Centers, while the students in the experimental group whose musical ability were determined were given priority. "Informed Consent Form" and "Informed Child Consent 
Form" were prepared for each student in the experimental group and the trainings were carried out after the children were signed by themselves and their parents.

\section{Data Collection Tool}

\section{Perceived Stress Level Scale (PSS)}

"Perceived Stress Level Scale" used in the study; It is a five-point Likert scale, developed by Cohen, Kamarc and Mermelstein (1983), consisting of fourteen items. The scale has a rating expression classified between "(5) Very Frequent" and "(1) Never". The scale also; It has been developed in three different forms with four, ten and fourteen questions. Seven items (4, 5, 6, 7, 9, 10 and 13 items) of the scale consisting of 14 items are reverse scored items. In 2013, Turkey reliability and validity study of the old and fellows conducted by the scale consists of fourteen substances, in the range of 16 to 23 years, 173 women and 61 tested a total of 234 university students, including boys and internal consistency coefficient so that the scale 0.84 determined as. The "test-retest" reliability coefficient was determined as 0.87 as a result of the studies performed.

\section{Demographic Information Form}

A "Demographic Information Form" was developed by the researcher in order to obtain information about gifted students included in the study. The aforementioned form students; It consists of questions about gender, class, current education level and the parents' interest in music. The data formed according to the answers given by the gifted students who participated in the study to these questions are shared in the Table 1,2,3,4.

\section{Participants}

Participants characteristics are presented as tables as below.

Table 1.

Demographic Characteristics (Gender)

\begin{tabular}{llccc}
\hline & & f & N & Total \\
\hline \multirow{2}{*}{ Control Group } & Frequency (n) & 135 & 170 & 305 \\
& Percent (\%) & $44,26 \%$ & $55,74 \%$ & $100 \%$ \\
\hline \multirow{2}{*}{ Experimental group } & Frequency (n) & 13 & 12 & 25 \\
& Percent (\%) & $52,00 \%$ & $48,00 \%$ & $100 \%$ \\
\hline
\end{tabular}

Table 2.

Demographic Characteristics (Class)

\begin{tabular}{|c|c|c|c|c|c|c|c|c|c|c|c|c|c|}
\hline & & 2 & 3 & 4 & 5 & 6 & 7 & 8 & 9 & 10 & 11 & 12 & $\stackrel{5}{0}$ \\
\hline Control & $\begin{array}{l}\text { Frequency } \\
\text { (n) }\end{array}$ & 10 & 32 & 84 & 52 & 38 & 15 & 21 & 19 & 10 & 15 & 9 & 305 \\
\hline Group & Percent $(\%)$ & $\begin{array}{l}3,28 \\
\%\end{array}$ & $\begin{array}{l}10,49 \\
\%\end{array}$ & $\begin{array}{l}27,54 \\
\%\end{array}$ & $\begin{array}{l}17,05 \\
\%\end{array}$ & $\begin{array}{l}12,46 \\
\%\end{array}$ & $\begin{array}{l}4,92 \\
\%\end{array}$ & $\begin{array}{l}6,89 \\
\%\end{array}$ & $\begin{array}{l}6,23 \\
\%\end{array}$ & $\begin{array}{l}3,28 \\
\%\end{array}$ & $\begin{array}{l}4,92 \\
\%\end{array}$ & $\begin{array}{l}2,95 \\
\%\end{array}$ & $\begin{array}{l}100 \\
00 \%\end{array}$ \\
\hline Experim & $\begin{array}{l}\text { Frequency } \\
\text { (n) }\end{array}$ & 0 & 3 & 5 & 8 & 3 & 0 & 0 & 2 & 4 & 0 & 0 & 25 \\
\hline $\begin{array}{l}\text { ental } \\
\text { group }\end{array}$ & Percent $(\%)$ & $\begin{array}{l}0,00 \\
\%\end{array}$ & $\begin{array}{l}12,00 \\
\%\end{array}$ & $\begin{array}{l}20,00 \\
\%\end{array}$ & $\begin{array}{l}32,00 \\
\%\end{array}$ & $\begin{array}{l}12,00 \\
\%\end{array}$ & $\begin{array}{l}0,00 \\
\%\end{array}$ & $\begin{array}{l}0,00 \\
\%\end{array}$ & $\begin{array}{l}8,00 \\
\%\end{array}$ & $\begin{array}{l}16,0 \\
\%\end{array}$ & $\begin{array}{l}0,00 \\
\%\end{array}$ & $\begin{array}{l}0,00 \\
\%\end{array}$ & $\begin{array}{l}100 \\
00 \\
\%\end{array}$ \\
\hline
\end{tabular}

Table 3.

Demographic Characteristics (Education Level)

\begin{tabular}{llcccc}
\hline & & $\begin{array}{c}\text { Primary } \\
\text { school }\end{array}$ & $\begin{array}{c}\text { Middle } \\
\text { School }\end{array}$ & High school & Total \\
\hline Control Group & Frequency (n) & 126 & 126 & 53 & 305 \\
& Percent (\%) & $41,31 \%$ & $41,31 \%$ & $17,38 \%$ & $100 \%$ \\
\hline Experimental & Frequency (n) & 8 & 11 & 6 & 25 \\
group & Percent $(\%)$ & $32,00 \%$ & $44,00 \%$ & $24,00 \%$ & $100 \%$ \\
\hline
\end{tabular}


Table 4.

Demographic characteristics (Family Members' Interest in Music)

\begin{tabular}{lllll}
\hline & & Yes & No & Total \\
\hline \multirow{2}{*}{ Control Group } & Frequency (n) & 90 & 215 & 305 \\
& Percent (\%) & $29,51 \%$ & $70,49 \%$ & $100 \%$ \\
\hline \multirow{2}{*}{ Experimental group } & Frequency (n) & 10 & 15 & 25 \\
& Percent (\%) & $40,00 \%$ & $60,00 \%$ & $100 \%$ \\
\hline
\end{tabular}

\section{Process}

Content of the religious music education practices conducted within the scope of the study

In order to achieve the aim of the research, a plan on "religious music education practices" was prepared by the researcher to be carried out with the experimental group. According to this plan, the researcher carried out training with twenty-five students in the experimental group for ten weeks, with four activity hours per week. The activity hour was planned to be forty minutes, accordingly, 160 minutes of training was carried out with the students in a week. The trainings were carried out in the form of distance online education, through the "Zoom" program, due to the covid-19 pandemic. The titles of the weekly trainings are as follows: 1- Definitions, 2- Music Forms, 3- Forms of Religion Music (Azan), 4- Forms of Religion Music (Takbir), 5- Forms of Religion Music (Salah), 6- Forms of Religion Music (Salah) 7- Forms of Religion Music (Divine), 8- Forms of Religion Music (Divine), 9- Forms of Religion Music (Breath), 10- Forms of Religion Music (Breath). It was determined that the student group in the experimental group regularly participated in the trainings. One of the trainings conducted with all experimental group students is shared in Figure 1.

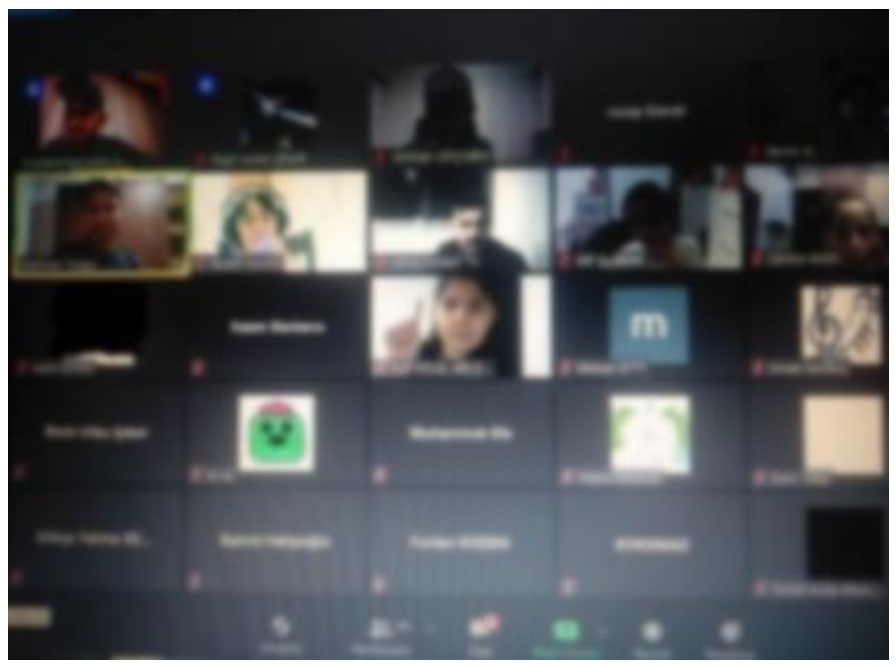

Figure 1.

A Frame from the Training Carried out with the Experimental Group

During the ten-week training, it was determined that the experimental group students took part in the trainings with interaction and absorbed religious music, with the contribution of their abilities in the field of music and their interest in the field.

\section{Data Analysis}

The information collected as a result of the literature review conducted to reveal the problem of the research was processed with the deductive method, which is defined from general to specific. The data obtained through the demographic information form of both the control group and the experimental group (independent variables) and the data collected for the "perceived stress level", which was prepared for the purpose of the study and constitutes the dependent variable, were analyzed by the researcher in the SPSS program.

In the analyzes made, the normal distribution status of the data set for statistical calculations was examined, and the results obtained are shared in Table 5 . 
Table 5.

Normal Distribution Test of Perceived Stress Scale Scores

\begin{tabular}{lcccccc}
\hline & \multicolumn{3}{c}{ Kolmogorov-Smirnov $^{\mathbf{a}}$} & \multicolumn{3}{c}{ Shapiro-Wilk } \\
\hline & Statistics & $\mathrm{df}$ & $\mathrm{p}$ & Statistics & $\mathrm{df}$ & $\mathrm{p}$ \\
Perceived Stress Scale &, 109 & 330 &, 000 &, 955 & 330 &, 000 \\
\hline
\end{tabular}

As can be understood from Table 5, it is recommended that the results of the Kolmogorov-Smirnov test should be considered if the sample group participating in the study has a numerical value of 50 and above. Accordingly, it was determined from the obtained data that "the data set did not show a normal distribution" ( $>>0.05)$. From this point of view, it is thought that it would be more appropriate to use non-parametric tests in statistical calculations for research. For this reason, for statistical calculations in research; frequency, percentage and Mann-Whitney U tests were used.

\section{Results}

Within the framework of the main problem of the study and the sub-problems emerging from this problem, the findings obtained from the data tool determined for the research are shared in detail below.

\section{Descriptive Analysis}

In the research, descriptive analysis was carried out first. In this context, the findings obtained by comparing the perceived stress levels of the students in the experimental group with the students in the control group are shared in Table 6.

Table 6.

Descriptive Statistics Results Regarding the Perceived Stress Levels of the Experimental Group Students

\begin{tabular}{lcccccc}
\hline & Experimental & Control & Experimental & Control & Experimental & Control \\
\hline & N & N & $\overline{\boldsymbol{X}}$ & $\overline{\boldsymbol{X}}$ & SD. & SD \\
\hline Perceived Stress & 25 & 305 & 2,8571 & 3,0080 &, 60644 &, 44911 \\
Current N & 25 & 305 & & & & \\
\hline
\end{tabular}

In Table 6, the experimental group formed by the specially talented students involved in religious music practices and the control group formed by the specially talented students who did not participate in these practices were compared. Accordingly, the perceived stress scores of the experimental group were found to be at a normal level (= 2.85) compared to the control group.

\section{Differentiation Status of the Experiment and Control Groups in Perceived Stress Levels}

The U-test was used to test whether the religious music practices performed had an effect on a significant difference in perceived stress levels of students in the control and experimental groups. Findings reached are presented in Table 7.

\section{Table 7.}

U-Test Results of the Perceived Stress Scores of Gifted Students according to their Participation in the Religious Music Practice Program

\begin{tabular}{llccccc} 
& Group & N & Average Rank & Rank Sum & U & p \\
\hline \multirow{2}{*}{ Perceived } & Experimental & 25 & 121,36 & 3034,00 & 2,70 &, $016^{*}$ \\
Stress & Control & 305 & 169,12 & 51581,00 & & \\
& Total & 330 & & &
\end{tabular}

Religious music training was applied to twenty-five students in the experimental group for ten weeks. Students in the control group continued their normal education. At the end of the ten-week trainings, it was determined that there is a significant difference between the perceived stress scores of gifted students who are and are not included in the applications, as can be seen in Table $7(\mathrm{U}=2.70, \mathrm{p}<.05)$. 


\section{Differentiation According to Gender in the Effect of Religious Music Practices on the Perceived Stress of Gifted Students}

When compared to the control group, the differentiation of the students in the experimental group of their religious music education according to the gender variable in the perceived stress levels was tested with the U-Test and the findings are presented in Table 8.

Table 8.

U-Test Result for the Differentiation of Gifted Students' Perceived Stress Scoress According to Gender

\begin{tabular}{llllllll}
\hline Gender & & Group & N & Average Rank & Rank Sum & U & p \\
\hline \multirow{4}{*}{ Male } & Perceived & Experimental & 13 & 88,38 & 1149,00 & 1,058 &, 798 \\
& Stress & Control & 170 & 92,28 & 15687,00 & & \\
& & Total & 183 & & & & \\
\hline \multirow{2}{*}{ Female } & Perceived & Experimental & 12 & 33,42 & 401,00 & 323,000 &, $001^{*}$ \\
& Stress & Control & 135 & 77,61 & 10477,00 & & \\
& & Total & 147 & & & & \\
& & & & & & & \\
\hline
\end{tabular}

As can be seen in Table 8, while there is no significant difference in male students ( $p>.05)$, a significant difference is observed in female students $(\mathrm{p}<.05)$. This significant difference in female students was calculated lower in perceived stress scores in favor of the experimental group.

Differentiation by Class Level in the Effect of Religious Music Practices on the Perceived Stress of Gifted Students

When compared with the control group, the differentiation of religious music practices in the perceived stress levels of the students in the experimental group according to the grade level variable was tested with the U-Test, and the findings are presented in Table 9.

Table 9.

U-Test Result For The Differentiation Of Gifted Students According To Their Grade Levels

\begin{tabular}{|c|c|c|c|c|c|c|c|}
\hline Class & & Group & $\mathbf{N}$ & Average Rank & Rank Sum & $\mathbf{U}$ & $\mathrm{p}$ \\
\hline \multirow{3}{*}{$3^{\text {rd }}$} & \multirow{3}{*}{$\begin{array}{l}\text { Perceived } \\
\text { Stress }\end{array}$} & 1 & 3 & 19,17 & 57,50 & 44,500 & 846 \\
\hline & & 2 & 32 & 17,89 & 572,50 & & \\
\hline & & Total & 35 & & & & \\
\hline \multirow{3}{*}{$4^{\text {th }}$} & \multirow{3}{*}{$\begin{array}{l}\text { Perceived } \\
\text { Stress }\end{array}$} & 1 & 5 & 14,10 & 70,50 & 55,500 & ,006* \\
\hline & & 2 & 84 & 46,84 & 3934,50 & & \\
\hline & & Total & 89 & & & & \\
\hline \multirow{3}{*}{$5^{\text {th }}$} & \multirow{3}{*}{$\begin{array}{l}\text { Perceived } \\
\text { Stress }\end{array}$} & 1 & 8 & 27,69 & 221,50 & 185,500 & 623 \\
\hline & & 2 & 52 & 30,93 & 1608,50 & & \\
\hline & & Total & 60 & & & & \\
\hline \multirow{3}{*}{$6^{\text {th }}$} & \multirow{3}{*}{$\begin{array}{l}\text { Perceived } \\
\text { Stress }\end{array}$} & 1 & 3 & 16,33 & 49,00 & 43,000 & ,519 \\
\hline & & 2 & 38 & 21,37 & 812,00 & & \\
\hline & & Total & 41 & & & & \\
\hline \multirow{3}{*}{$9^{\text {th }}$} & \multirow{3}{*}{$\begin{array}{l}\text { Perceived } \\
\text { Stress }\end{array}$} & 1 & 2 & 4,25 & 8,50 & 5,500 & ,114 \\
\hline & & 2 & 19 & 11,71 & 222,50 & & \\
\hline & & Total & 21 & & & & \\
\hline \multirow{3}{*}{$10^{\text {th }}$} & \multirow{3}{*}{$\begin{array}{l}\text { Perceived } \\
\text { Stress }\end{array}$} & 1 & 4 & 7,75 & 31,00 & 19,000 & ,945 \\
\hline & & 2 & 10 & 7,40 & 74,00 & & \\
\hline & & Total & 14 & & & & \\
\hline
\end{tabular}

As can be seen in Table 9, some class levels could not be analyzed due to inadequacies in some data. When the classes analyzed are examined; While there was no significant difference in perceived stress levels of gifted students 
in 3rd, 6th and 9th grades ( $\mathrm{p}>.05)$, a significant difference was encountered in perceived stress levels of gifted students studying in 4 th grade $(\mathrm{p}<.05))$. It is understood that this difference is lower in perceived stress scores in favor of the experimental group.

Differentiation Status According to Education Levels in the Effect of Religious Music Practices on the Perceived Stress of Gifted Students

When compared with the control group, whether the religious music practices have any significant difference in the perceived stress levels of the gifted students in the experimental group, according to the educational level variable, was tested with the U-Test and the findings reached are shared in Table 10.

Table 10.

U-Test Result for the Differentiation of Gifted Students according to Education Level

\begin{tabular}{|c|c|c|c|c|c|c|c|}
\hline Education Level & & Group & $\mathbf{N}$ & Average Rank & Rank Sum & $\mathbf{U}$ & $\mathrm{p}$ \\
\hline & & 1 & 2 & 48,00 & 96,00 & 93,000 & ,409 \\
\hline \multirow[t]{3}{*}{ Primary School } & Perceived Stress & 2 & 147 & 75,37 & 11079,00 & & \\
\hline & & Total & 149 & & & & \\
\hline & & 1 & 10 & 31,15 & 311,50 & 256,500 & ,034* \\
\hline \multirow[t]{3}{*}{ Middle School } & Perceived Stress & 2 & 87 & 51,05 & 4441,50 & & \\
\hline & & Total & 97 & & & & \\
\hline & & 1 & 13 & 35,23 & 458,00 & 367,000 & ,241 \\
\hline \multirow[t]{2}{*}{ High School } & Perceived Stress & 2 & 71 & 43,83 & 3112,00 & & \\
\hline & & Total & 84 & & & & \\
\hline
\end{tabular}

When Table 10 is examined, there is no significant difference in primary and high school students ( $>>.05)$, while there is a significant difference in secondary school students $(\mathrm{p}<.05)$. This differentiation in perceived stress scores was found to be in favor of the experimental group.

Differentiation Status According to Parents' Interest in Music in the Effect of Religious Music Practices on the Perceived Stress of Gifted Students

When compared with the students in the control group, whether there is a difference in the perceived stress levels of the students in the experimental group of religious music practices according to the students 'parents' level of interest in music was tested with the U-Test and the findings obtained are presented in Table 11.

Table 11.

U-Test for the Differentiation of Gifted Students according to Parents' Interest in Music

\begin{tabular}{|c|c|c|c|c|c|c|c|}
\hline \multicolumn{2}{|c|}{ Interest in Music } & Group & $\mathbf{N}$ & Average Rank & Rank Sum & $\mathbf{U}$ & $\mathrm{p}$ \\
\hline \multirow{3}{*}{ Interested } & \multirow{3}{*}{ Perceived Stress } & 1 & 10 & 50,05 & 500,50 & 445,500 & ,959 \\
\hline & & 2 & 90 & 50,55 & 4549,50 & & \\
\hline & & Total & 100 & & & & \\
\hline \multirow{3}{*}{ Not interested } & \multirow{3}{*}{ Perceived Stress } & 1 & 15 & 66,23 & 993,50 & 873,500 & ,003* \\
\hline & & 2 & 215 & 118,94 & 25571,50 & & \\
\hline & & Total & 230 & & & & \\
\hline
\end{tabular}

When Table 11 is examined, although no significant difference was found in students with parents who are interested in music $(p>.05)$, a significant difference $(p<.05)$ was found in the perceived stress levels of students with parents who are not interested in music. This difference was found to be lower in perceived stress scores in favor of the experimental group.

\section{Conclusion and Discussion}

Conclusions were reached within the framework of the findings obtained in the study, and suggestions were made based on these results. Based on the findings obtained within the framework of the sub-problems that were revealed based on the main problem of the study, the following conclusions were reached. 
Main Problem: Do religious music education practices have an impact on the perceived stress of gifted children?

Based on the findings obtained in the study, it was determined that the perceived stress scores were at normal level $(\bar{X}=2.85)$. According to this; It was concluded that "religious music education practices have no positive or negative effect on the perceived stress levels of gifted children".

Sub Problem 1. Does the gender factor play a role in the effect of religious music education practices on the perceived stress of gifted children? In the study, the difference in the perceived stress levels of gifted students who are included in religious music education practices and those who do not participate in this education, depending on the gender variable, was examined. Accordingly, it was found that there is a significant difference among female students compared to male students.

When the literature is examined, it has been determined that there are differences in perceived stress levels depending on gender, and accordingly, there are studies showing that the perceived stress levels of female students are higher than that of male students (Kaçan Softa et al., 2015; Eraslan, 2010).

According to the results of these studies, based on the findings of this research, it has been concluded that "female students whose perceived stress levels are generally higher than male students have decreased these stress levels as a result of religious music education practices".

In the master's thesis titled "The Effect of Religious Music Practices on Self-Esteem of Children with Mild Mental Disabilities” prepared by Özsağır (2017) in the Department of Turkish Religious Music, Department of Islamic History and Arts, Institute of Social Sciences of Marmara University, The role of the gender variable in the effect of disabled children on self-esteem was examined. According to the results of the study, there was no effect of religious music education practices on the gender variable factor. The results obtained in this study of Özsağır do not show parallelism with the results obtained in this study.

Sub-Problem 2. Do class levels have a role in the effect of religious music education practices on the perceived stress of gifted children? As a result of the analyzes conducted in the study, no differentiation was found among gifted students studying in the $3^{\text {rd }}, 6^{\text {th }}$ and $9^{\text {th }}$ grade, while a significant difference was found in the perceived stress levels of the gifted students studying in the $4 \mathrm{t}^{\mathrm{h}}$ grade. Accordingly, in the study; It has been concluded that "religious music education practices may be more effective at some grade levels and in reducing perceived stress in gifted students".

Sub Problem 3. Does the education level the child attends have a role in the effect of religious music education practices on the perceived stress of gifted children?

In the research; While no significant difference was found in gifted students studying at primary and high school levels, it was found that there was a significant difference in perceived stress levels of gifted students studying at secondary school level. It was concluded that the perceived stress scores related to this differentiation were lower in favor of the experimental group. Although it is not a specific result, this situation can be interpreted as "religious music education practices reduce the perceived stress in some educational levels".

Sub-Problem 4. Does interest in music play a role in the effect of religious music education practices on the perceived stress of gifted children? In the study, no significant difference was found in gifted students with parents who are interested in music, while a significant difference was found in the perceived stress level of gifted students with parents who are not interested in music. It was concluded that this difference was lower in perceived stress scores in favor of the experimental group.

It is a known fact that parental attitudes and behaviors have a great impact on children, especially in the musical education process. Parental behavior, which makes a child realize that he is free, is more effective in focusing on the education and developmental process of his child more comfortably than the parent behaviors with a pedestal structure, and thus success in his education (Pomerantz et al., 2005). Gürgen (2018: 712-713) stated in his article entitled "Parental involvement in the piano learning process" that many parents expressed positive words about their children being able to play the piano. He stated that they started.

In his master's thesis titled 'The Effect of Religious Music Education in Imam Hatip High Schools on Students' Self-Esteem” prepared by Öztürk (2018: 32) in the Department of 'Turkish Religious Music, Department of Islamic History and Arts, Institute of Social Sciences of Marmara University, Does the type of music most frequently listened to in the family play a role in the effect of musical education on students' self-esteem? " As a result of the analysis on the sub-problem, it was concluded that "the music genre that is often listened to together in the family has no effect on students' self-esteem." No similarity was found between the results obtained in the aforementioned study and the results obtained in this study. 


\section{Recommendations}

Findings of this research; The conditions and time in which the research was conducted, the sample in which the religious music education practices were carried out, the measurement tool used, and the applied techniques were limited. In this respect, this research, which was carried out with specially gifted children, is the first time in the field. It has the feature of being a reference to new studies that will be a continuation of this research in the future and which will be developed and made more inclusive. Based on this, the following recommendations have been made for new studies on the subject:

In the study, students in the experimental group participated in religious music education practices for a total of ten weeks, four activity hours per week. These trainings; Due to the fact that it is limited to experimental group students and that these trainings are carried out in the form of remote online education due to the covid-19 pandemic, it may not be possible to reach the desired quality of education and the targeted number of student groups. For this reason, face-to-face religious-music education practices may be more effective on students, thus achieving a positive reduction in students' perceived stress levels.

$>$ Special talented students who took part in the experimental group of the research; Another study to be carried out by making use of the opinions of their parents, administrators, counsellors and other teachers may contain much more efficient information to interpret the results of this study.

$>$ In Turkey, the Turkish Religious Music education of the relationship between perceived stress levels by making the application more clearly in the longitudinal direction in order to establish more scientific research will be useful for the development of this area.

\section{Limitations of Study}

Eight Science and Art Centers operating in Ankara (Keçiören Science and Art Center, Mamak Science and Art Center, Yasemin Karakaya Science and Art Center, Etimesgut Science and Art Center, Sincan Science and Art Center, Çubuk Science and Art Center, Yenimahalle Science and Art Center and Martyr Hüseyin Gültekin Science and Art Center), Twelve female and thirtheen male students with special talent who are studying in these Science and Art Centers and determined as the experimental group according to the data obtained as a result of the scale applied for the research, with the religious music education practices planned by the researcher, it is limited by the scale named "Perceived Stress Level Scale".

\section{Acknowledgement}

I would like to thank my thesis advisor, Dr. Sadettin Volkan Kopar, the director of the conservatory Dr. Serbülent Arpa and Head of Department Assoc. Dr. Mehmet Traşc1 and my wife Serap Dereli, my children Emir Dereli and Zeynep Betül Dereli whose moral support I always feel by my side.

\section{Biodata of Author}

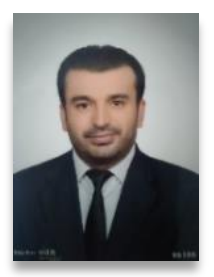

Recep Dereli received his graduate degree from Niğde University, Faculty of Education, Department of Music Teaching in 2005. He is continuing his Master of Arts at Yildirım Beyazıt University Turkish Music State Conservatory, Department of Turkish Religious Music History. Since 2019, he has been working as a music teacher at Keçiören Science and Art Center, which has been raising gifted students. He took part in many national choral festivals, concerts and competitions. He worked in the field of innovative approaches in music education and carried out projects by participating in workshops in the field of gifted people. Affilation: Ministry of Education, Keçiören Science and Art Center, Ankara, Turkey. Email: recep_dereli@hotmail.com ORCID: 0000-0003-0564-9004

\section{References}

Baltaş, A. and Baltaş, Z. (2002). Stres ve Başa Çıkma Yolları, (21. ed), İstanbul: Remzi Kitapevi.

Betts, G.T. and Neihart, M.F. (1985). Eight Effective Activities To Enhance The Emotional And Social Development Of The Gifted And Talented. Roeper Review, 8, 18-23.

Cohen, S., Tom, K. and Robin M. (1983). A Global Measure Of Perceived Stress Reviewed. Journal of Health and Social Behavior, 24(4), 385-396.

Eraslan, Ç. B. (2010). Öğretmen Adaylarının Üstün Yetenekli Öğrencilere Yönelik Metaforik Alg1ları. International Journal of Social Research, 3(12), 140-154. 
Gürgen, İ. (2018). Hammurabi Kanunları'nda ve Tevrat'ta kadınla ilgili hükümlerin değerlendirilmesi. Celal Bayar Üniversitesi, Journal of Social Sciences, 16(4), 333-348.

Güvenç, O. R. (1985). Türklerde ve Dünyada Müzikle Rubi Tedavinin Tarihçesi ve Günümüzdeki Durumu, İstanbul University, Cerrahpaşa Faculty of Medicine, Department of Psychiatry, Unpublished PhD Thesis, İstanbul.

Howard, R. W. (1995). Learning And Memory: Major Ideas, Principles, Issues, And Applications, Westport, CT: Praeger.

Kaçan Softa, H., Karaahmetoğlu, G. U. and Çabuk, F. (2015). Lise Son Sınıf Öğrencilerinin Sınav Kaygisı ve Etkileyen Faktörlerin İncelenmesi. K. Ü. Journal of Kastamonu Education Faculty, 23(4), 1481-1494.

Mark, G. M. and Smith, A. P. (2008). Stress Models: A Review And Suggested New Direction. Occupational Health Psychology, 3 , 111-144. Downloaded from https://pdfs.semanticscholar.org/a2a1/f31f2bea80c1da57501cc0311a94daa087d7.pdf on 15.03.2021.

Neihart, M. and Yeo, L. S. (2018). Psychological Issues Unique To The Gifted Student. In S. I. Pfeiffer, E. Shaunessy-Dedrick ve M. Foley-Nicpon (Eds.), APA Handbook of Giftedness and Talent, pp. 399-415, Washington, DC: American Psychological Association.

Özsağir, A. (2017). Dini Musiki Uygulamalarmm Hafif Zihinsel Engelli Cocuklarn ÖzSaygısına Olan Etkisi, Marmara University Institute of Social Sciences, Department of Islamic History and Arts, Department of Turkish Religious Music, Unpublished Master's Thesis, İstanbul.

Öztürk, L. (2018). Imam Hatip Liselerindeki Dini Musiki Eğitiminin Ögrencilerin Öz Saygısma Olan Etkisi, Marmara University Institute of Social Sciences, Department of Islamic History and Arts, Department of Turkish Religious Music, Master's Thesis, İstanbul.

Öztürk, M. (2019). Hatay'da Dinî Mûsikî, Harran University Institute of Social Sciences Department of Islamic History and Arts, Unpublished Master's Thesis, Sanliurfa.

Pfeiffer, S. I. and Stocking, V. B. (2000). Vulnerabilities Of Academically Gifted Students. Special Services in the Schools, 16(1-2), 8393.

Pomerantz, E. M., Grolnick, W. S., \& Price, C. E. (2005). The Role Of Parents In How Children Approach Achievement: A Dynamic Process Perspective. In A.J. Elliot \& C.S. Dweck (Eds.), Handbook Of Competence And Motivation, pp. 259-278, New York: Guilford.

Saranli, A. G. (2017). Okul Öncesi Dönemdeki Erken Müdahale Uygulamalarına Farklı Bir Bakış: Üstün Yetenekli Çocuklar İçin Erken Zenginleştirme [A Different Look At Early Intervention Practices In Pre-School Period: Early Enrichment For Gifted Children]. Education And Science, 42(190), 343-359, http://dx.doi.org/10.15390/EB.2017.7062

Selye, H. (1956). The Stress Of Life, New York: McGraw-Hill Book Co.

Selye, H. (1965). The Stress Of Life New Focal Point For Understanding Accidents. Nursing Forum, 4(1), 28-38. doi:10.1111/j.1744-6198.1965.tb01011.x

Tachè, J. and Selye, H. (1985). On Stress and Coping Mechanisms. Issues in Mental Health Nursing, 7(1-4), 3-24. doi:10.3109/01612848509009447 
